
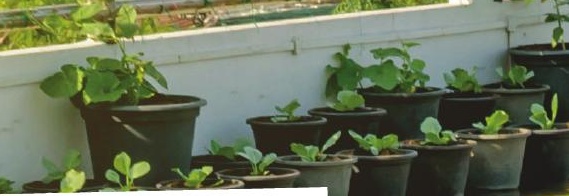

\title{
EXPERIENCE, GROW AND LEARN TO BE A HORTICULTURALIST
}

ODILE HUCHETTE, FROM THE NC A\&T STATE UNIVERSITY IN GREENSBORO, USA, HAS DEVELOPED THE URBAN FOOD PLATFORM, A THRIVING EDUCATIONAL SPACE THAT ENABLES STUDENTS TO PUT SCIENTIFIC LEARNING INTO PRACTICE AND TRAINS THEM TO BE THE NEXT GENERATION OF HORTICULTURE PROFESSIONALS

\section{TALK LKE A HORTICULTURALIST}

CULTIVAR - a plant produced by selective breeding, usually for a particular characteristic, such as taste, colour or resistance to pests

GREENHOUSE - a structure with walls and roof made mostly of a transparent material, such as glass or polycarbonate. Inside, plants can grow under controlled conditions

HORTICULTURE - the branch of agriculture concerned with growing, improving and promoting cultivated plants used for food, medicinal purposes or aesthetic purposes, such as fruits, vegetables, flowers, herbs, and ornamental plants

HYDROPONICS - the technique of growing plants in a solution containing dissolved nutrients. Plants can have their roots completely submerged in this nutritious liquid, or be supported by an inert medium

MICROCLIMATE - the particular climate of a small or defined area
SUSTAINABILITY - refers to the ability to preserve environmental resources for future generations while maintaining a balance with equity and economic principles

URBAN AGRICULTURE - "The growing, processing and distribution of food and other products through intensive plant cultivation and animal husbandry in and around cities." (Bailey and Nasr, 2000)
In our world of convenience and technology, it is easy to forget the complex science behind many everyday aspects of our lives, and food production is no exception. From plant propagation to disease management, managing micro-climates and practising sustainability, the intricacies of horticulture are wide and varied, which is why Odile Huchette of NC A\&T State University in Greensboro, USA, is determined to get her students out of the classroom and into a living learning space, the Urban Food Platform.

With many of her students coming from an urban background, lacking hands-on experience in horticulture or agriculture, Odile decided to immerse them in the practical aspects of horticultural science, alongside the academic learning of the scientific concepts required. In the Urban Food Platform (UFP) students conduct scientific research, collecting crop and climatic data from sowing to harvest, and manage all aspects of urban food production in a working horticulture space that contains a greenhouse, raised beds, cold frames and hydroponics. Students also organise outreach activities to engage the campus and wider local community with the UFP.

\section{INTRODUCING THE UFP}

"With rural communities shrinking and urban and suburban populations growing, a lot of students coming into agricultural sciences have little practical experience in horticulture and food production," explains Odile.

As a solution to this problem, Odile's brilliant programme allows students to understand how all the components of horticulture come together in practical terms - she believes students need to understand the connection between practical agriculture and the scientific theory learned in the classroom. "It is

important to include experiential learning and develop programmes that are relevant to urban and suburban students," she says.

The UFP culminated with a greenhouse built by the students. "It ended up being a very successful project, which contributed to participants developing a sense of community, and helped build confidence," says Odile. "The effort required also taught them about leadership, community, soft skills and the value of teamwork." The greenhouse project was completed with the installation of raised vegetable beds with a drip irrigation system. 


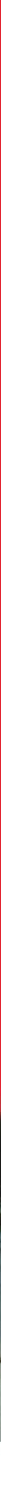

stations, so students can record and monitor microclimate data, such as soil temperature, air temperature, light and humidity. Students observe plants and connect their observations with weather data in order to evaluate the effect the microclimate has on the growth of the plants. "We're in an urban environment but we do have trees that are partially shading our platform," explains Odile. "So, we look at the effect of the shade on the beds and with some plants it's really visible. This helps to illustrate the requirements for growing food in an urban setting and, if problems arise, students are asked to identify, research and find solutions. Students can also use data to evaluate the risk of disease using a forecasting system associated with the weather stations (such as for tomato plant diseases, which we have). They can then discuss possible actions to take based on the forecast of the system."

This approach allows students to learn about experimental design and understand how data analysis is vital to assess how different cultivars perform. Students can see the impact of different growing techniques, as well as factors such as planting density, water, nutrition and microclimate - all specific to growing food in an urban setting. The hands-on application of science facilitated by the UFP develops students' independence - and their professionalism.

horticulture, we cannot force or manipulate time that easily!"

The UFP also helps students to learn from mistakes. "Students are able to go through the process of diagnostics, identifying a problem and researching a solution." When students are faced with a plant suffering from a fungal disease, bacteria or virus, they will have to make observations, apply their knowledge and work to solve the problem. "We have a good diversity of plants," says Odile, "so, there are always case studies for them to apply their classroom knowledge to."

\section{THE END GOAL}

Motivated by her desire to provide the highest quality of education possible for her students, Odile gets them out of the classroom and into the UFP on a weekly basis. "I do not believe they can get the best level of education and knowledge if they are not experiencing the concepts we are teaching them," she explains. "For instance, when we talked about using a soil test as an example for building a fertility programme for crops, we were able to take our own soil samples, send them to the lab and get results that were more tangible to us. We discussed the results together, how to interpret the data and what the fertility of the soil would require us to plan for." The decisions that
Odile's students make are based on real life data they have collected - and their learning is all the greater for it.

\section{SUSTAINABILITY}

Odile knows that sustainability is of huge importance to horticulture in general, but also to students wanting to further their skills in the field. The UFP allows her to teach students that conducting processes systematically and thoughtfully is vital to sustainable practice. She explains, "We do not do things automatically, without understanding. From being efficient with our water use to only ever seeing pesticides as a last resort in cases of plant disease, sustainability comes through care and planning."

As the UFP is a small-scale space, being sustainable can be easier than in large-scale crop production. However, this is a good model to teach students about the essentials, such as testing soil before applying fertilisers, managing the start of a disease, and observing the different plant stages in order to develop an understanding of the crop needs in response to the environment. "I am teaching students a holistic approach, where we are understanding 
what makes a healthy plant environment and what is needed to grow an optimum crop."

\section{COMMUNITY}

The joy of the UFP is that this connection goes beyond Odile and her students and into the wider community. Recently, Odile was asked by the campus' chef to provide food for the university's Earth Day celebrations. Students were able to showcase sweet potatoes, lettuce, kale and herbs they had propagated and grown themselves. The chef was very happy with the quality of the produce and the students were proud of their achievements. Odile says, "From learning the time of propagation to the harvesting, including the growing of speciality herb crops, the students did everything from A to Z." Such a project also requires a huge amount of teamwork, something that Odile instils in her students when thinking about food production in general. "Students need to understand that it takes a lot of different people to actually get food in place - food production requires a myriad of jobs."

\section{LOOKING AHEAD}

Not only is the UFP an essential learning space for Odile and her students, it is also a visible and celebrated space on the university campus. But the learning does not stop there; the university's off-campus Student and Community Farm is also being developed to facilitate even more experiential learning. Offering insights into food production on a larger scale, the farm can be overwhelming to some students at the early stages of their learning journey. However, with the UFP as their foundation, Odile's students have the experience, skills and confidence such work will require.

The UFP is a springboard for scientific education, practical experience, sustainability awareness and community connections. It is multi-faceted and developing constantly; a thriving space for growth in more ways than one. The future looks bright for the Urban Food Platform and the next generation of horticulturalists it is training.

"Many thanks to my colleagues Dr Randle, Dr Yang and Ms Alexandra Wofford for their assistance in bringing this project to reality and making it a success," says Odile.

\section{EXPLORE A GAREER IN HORTICULTURE}

- There is a huge range of opportunity in the field. You can choose a career in soil science, agriculture, ecology, or botany.

Odile's academic research interests include breeding and genetics, plant disease, and local and urban food production systems, while her industry experience has included her role as an onion breeder.

Horticulturists can get certifications from organisations such as:

The American Society for Horticultural Science www.ashs.orgl

The American Society of Agronomy www.agronomy.orgl

- According to the US Bureau of Labour Statistics, salaries in 2020 relating to horticulture, plant and soil science, and agriculture and food science ranged between $\$ 69,000$ and $\$ 73,000$ a year. 


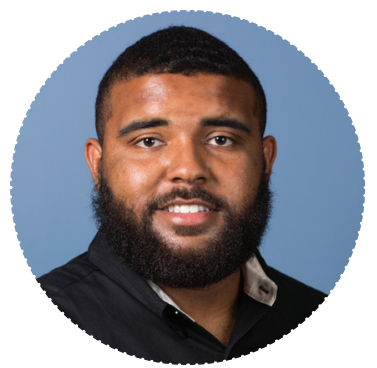

NAME: TREQUAN MCGEE

\section{CURRENT ROLE: PHD}

STUDENT IN HORTICULTURE

SCIENCES AT THE

UNIVERSITY OF FLORIDA
"Being able to engage the community around food was a special feeling. To see folks get their hands dirty, form fellowship and bond with others while growing their own food brought me so much joy.

A lot of the experiential learning prepared me for my graduate studies. You learn so much by doing the practical experience is unmatched. The material you learn in class really hits home once you put it into practice.

The UFP taught me that not everyone appreciates agriculture. I had to learn that though they might not initially appreciate it, it is something people interact with every day and a little education around it can go a long way.

My great grandmother's love for plants got me interested in horticulture initially. Once we started working in the garden, I realized there is a whole world that plants experience that the average person does not even consider. I often find myself taking the road less travelled and, well, here I am now studying for my PhD in horticulture sciences!
I am proud of the kids I have had the honour of interacting with. During my studies, I have had a couple experiences that have allowed me to get young kids out in the garden and touring agricultural operations. To see the shock and excitement in their eyes when they learned about agricultural things was amazing.

I hope to continue having opportunities to develop the next generation of agricultural leaders and to get more underrepresented people involved in this wonderful industry that has so much to offer.

I would advise anyone looking to study horticulture to get as much hands-on experience as possible and to not shy aware from some of the hard work that comes with agriculture. There are so many career options - traditional farming is only a small percentage of the overall agricultural jobs out there. Experiences on spaces such as the UFP are very enriching and I recommend them to anyone willing to embrace them."

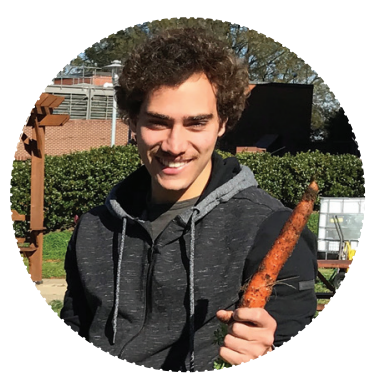

NAME: BAKER ZITAWI

CURRENT ROLE: GRADUATE RESEARCH ASSISTANTI GRADUATE STUDENT IN NATURAL RESOURCES AND ENVIRONMENTAL DESIGN
"The most rewarding part of my work at the UFP is definitely the people l've met along the way and how they've helped me grow and develop my skills as a person and horticulturist.

This experiential learning provided me with firsthand experience of efficiently growing crops in a small-scale urban environment. Through this experience, I was able to learn why what we cover in lectures is important and appreciate the benefits of applying proper technique.

My horticultural skills were developed through everyday work. Life skills such as communication and teamwork were developed while working with less experienced students and volunteers. You have to take the time to teach and guide them along the way.

I took horticultural classes in high school but went into university as chemistry major. In my junior year studying chemistry, I got a part-time job working in a greenhouse. I loved the work, so I transferred schools and changed majors!

My proudest achievement would be the level of responsibility I am now trusted with on the platform, coupled with watching the platform grow and improve year after year.

I'm not sure what the future holds, but I would like to study more proteomics and develop a deeper understanding of how biochemical pathways function in plants and then utilize that knowledge to breed improved plant varieties.

The best advice I can offer would be to start reading scientific papers early, then pursue the topic you find most interesting." 